\title{
MEDIA DAGANG GAME UNTUK MENINGKATKAN HASIL BELAJAR SISWA PADA MATERI USAHA DAGANG MATA PELAJARAN AKUNTANSI
}

\author{
Ameliasari Tauresia Kesuma \\ MAN Salatiga, Kota Salatiga, Jawa Tengah \\ Email: leakesuma@gmail.com
}

\begin{abstract}
Abstrak
Media Dagang Game adalah sebuah media simulasi yang dibuat berdasarkan permainan Monopoly, tetapi disesuaikan dengan aturan transaksi usaha dagang sesuai kompetensi dasar yang harus dipahami siswa kelas XII. Penelitian ini merupakan penelitian pengembangan metode dan strategi pembelajaran media dagang game untuk meningkatkan hasil belajar siswa mata pelajaran akuntansi pada materi usaha dagang. Hasil penelitian menunjukkan bahwa Media Dagang Game dapat meningkatkan hasil belajar siswa yang ditunjukkan dari nilai ketuntasan belajar dan rerata hasil belajar siswa saat pra penelitian, siklus 1 dan siklus 2.
\end{abstract}

Kata kunci: hasil belajar, dagang game, akuntansi

\section{Pendahuluan}

Lippicott dan Pergola (2009) menyebutkan bahwa jenis pedagogi "edutainment" seperti permainan dan simulasi yang memanfaatkan nilai hiburan dapat mendukung pembelajaran akademis. Peneliti sebelumnya Tanner and Lindquist (1998) dalam Halloran (2009) mengungkapkan setelah menggunakan board monopoli pada kelas junior akuntansi, siswa memiliki persepsi positif pada pembelajaran akuntansi. Demikian pula yang dilakukan Gamlath (2007) yang menggunakan board Monopoly untuk mengajar akuntansi, hasilnya siswa meningkat kemampuannya dalam memahami akuntansi, juga keterampilan interpersonalnya, dibandingkan cara tradisional ceramah atau tugas. Akuntansi adalah salah satu mata pelajaran di Madrasah Aliyah dan merupakan bagian dari pelajaran ekonomi, mempunyai fungsi dan tujuan untuk mengembangkan pengetahuan, keterampilan dan sikap rasional, teliti, jujur dan bertanggungjawab melalui prosedur pencatatan, pengelompokan, pengikhtisaran transaksi keuangan perusahaan dan penyusunan laporan keuangan secara benar menurut prinsip akuntansi yang berlaku, sehingga memberi manfaat bagi kehidupan mereka (Depdiknas, 2004).

Penelitian Homan (2013) mengungkapkan, akuntansi termasuk pelajaran yang sulit menurut siswa. Persepsi siswa mengenai sulitnya mempelajari akuntansi diduga karena proses belajar belum dilakukan secara aktif, padahal keaktifan siswa dalam proses belajar dapat menjadikan belajar lebih bermakna. Makna dalam hal ini merupakan hasil bentukan siswa sendiri yang bersumber dari apa yang mereka lihat, rasakan dan alami (Aunurrahman, 2009). Pra penelitian yang dilakukan menunjukkan hasil belajar mata pelajaran akuntansi 84,37\% atau 27 dari 32 siswa kelas XII IS 1 masih berada dibawah KKM 75 dengan nilai rata rata 45,63. 
Berdasarkan beberapa penelitian di atas dan kondisi rendahnya hasil belajar kelas XII IS 1 mendorong penulis untuk membuat media simulasi yang memudahkan siswa belajar akuntansi usaha dagang. Media pembelajaran ini disebut dengan Dagang Game, sebuah media simulasi yang dibuat berdasarkan pada aturanaturan dalam permainan Monopoly, tetapi disesuaikan dengan aturan transaksi usaha dagang sesuai kompetensi dasar yang harus dipahami siswa kelas XII IS. Media simulasi modifikasi dari permainan Monopoly Dagang Game, diharapkan dapat meningkatkan hasil belajar siswa, dan membuat mereka kasmaran belajar.

Rumusan masalah dalam penelitian ini adalah bagaimanakah proses peningkatan hasil belajar akuntansi melalui media Dagang Game kelas XII IS 1 MAN Salatiga Semester 1 Tahun Pelajaran 2016/2017? Berdasarkan permasalahan tersebut, peneliti melakukan penelitian tindakan kelas yang bertujuan untuk mengetahui bagaimana media Dagang Game dapat meningkatkan hasil belajar siswa kelas XII IS 1 MAN Salatiga.

Manfaat teoretis dari penelitian ini adalah untuk memberikan sumbangan pemikiran dan sebagai tolok ukur kajian penelitian lebih lanjut untuk perbaikan mutu pendidikan dan meningkatkan kompetensi siswa, khususnya untuk pencatatan jurnal umum dan jurnal khusus pada akuntansi usaha dagang. Penelitian ini juga diharapkan memberi manfaat praktis bagi siswa, guru dan dunia pendidikan, sebagai berikut. Manfaat praktis yang dapat diperoleh oleh siswa adalah memudahkan memahami materi pembelajaran akuntansi usaha dagang, menumbuhkan rasa cinta belajar akuntansi, menambah pengalaman baru dalam pembelajaran akuntansi, meningkatkan rasa empati, percaya diri, kejujuran dan kebersamaan. Manfaat praktis lainnya yang dapat diperoleh oleh guru dan dunia pendidikan dari penelitian ini sebagai berikut; (1) Menambah variasi model pembelajaran sebagai alternatif untuk meningkatkan kemampuan siswa memahami pencatatan transaksi dalam jurnal umum dan jurnal khusus usaha dagang, untuk selanjutnya disusun satu siklus akuntansi usaha dagang; dan (2) Meningkatkan keterampilan mengelola kegiatan belajar mengajar.

\section{Kajian Pustaka dan Hipotesis Tindakan}

Dagang game adalah media simulasi yang dibuat oleh penulis untuk mempermudah siswa dalam memahami pencatatan jurnal umum dan jurnal khusus pada akuntansi usaha dagang. Media ini didesain secara cermat sehingga siswa mengalami sendiri apa yang terjadi pada saat transaksi, mengapa akun tersebut masuk di sebelah debet, mengapa di kredit.

Aturan Dagang Game mirip dengan permainan Monopoly bedanya adalah, yang mereka beli dan jual adalah toko atau usaha dagang, tidak ada kotak dana umum dan kesempatan tetapi pandora box. Dalam pandora box terdapat kartu kartu berisi transaksi yang terjadi pada semua toko dan usaha dagang yang ada, ditambah retur pembelian, retur penjualan, berbagai beban yang timbul dan semua transaksi yang mungkin terjadi pada usaha dagang. 

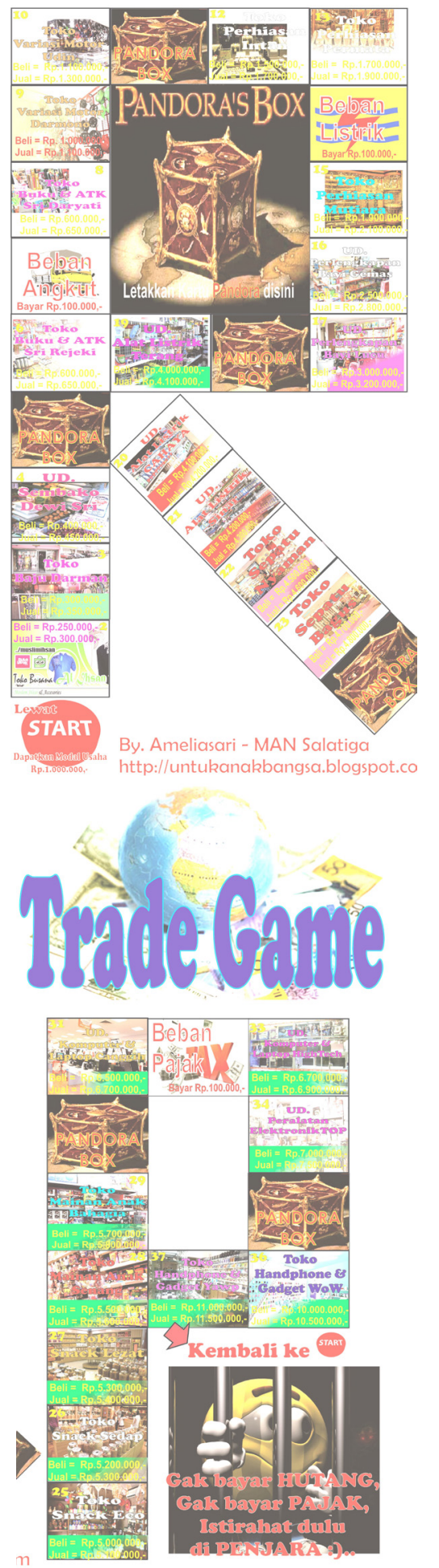

Gambar 1. Board Dagang Game
Pada permainan Dagang Game siswa dikelompokkan menjad 4 - 5 kelompok. Masing masing kelompok diberi satu set permainan Dagang Game yang terdiri dari satu set kartu Pandora Box, satu set kartu kepemilikan tanah, satu set kartu dadu dan satu set uang yang terdiri dari pecahan Rp. 10.000, Rp.50.000, Rp. 100.000, Rp.200.000, Rp.300.000, Rp. 500.000, Rp.1.000.000, Rp. 5.000.000. Semua uang dibuat dan dicetak sesuai dengan kebutuhan pencatatan dalam perusahaan dagang.

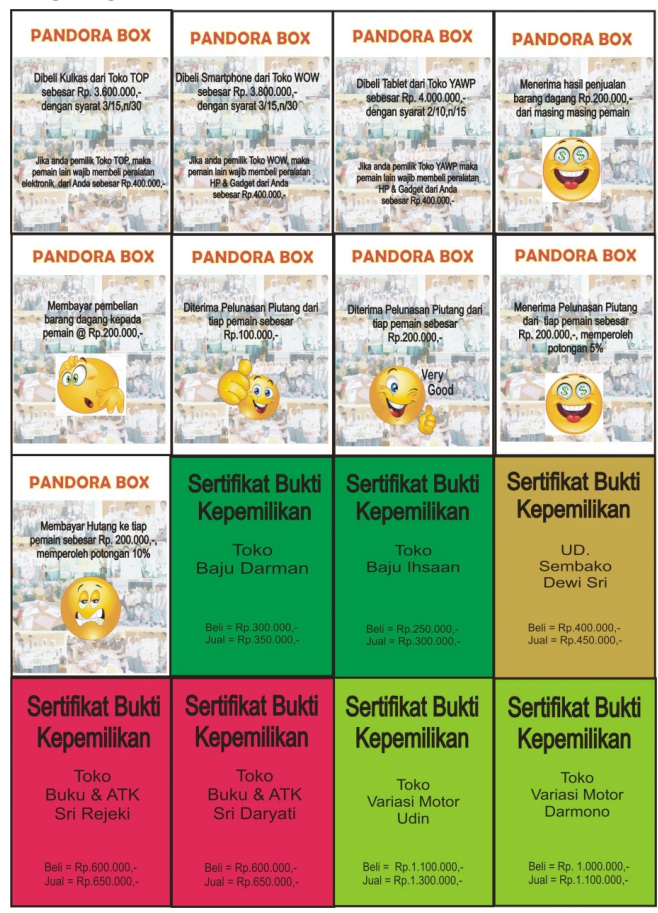

Gambar 2. Sebagian contoh pandora box dan sertifikat kepemilikan toko

Untuk mempermudah pemahaman transaksi yang terjadi di usaha dagang maka dibuatlah kartu pandora box yang berisi transaksi yang didesain sesuai dengan board Dagang Game. 


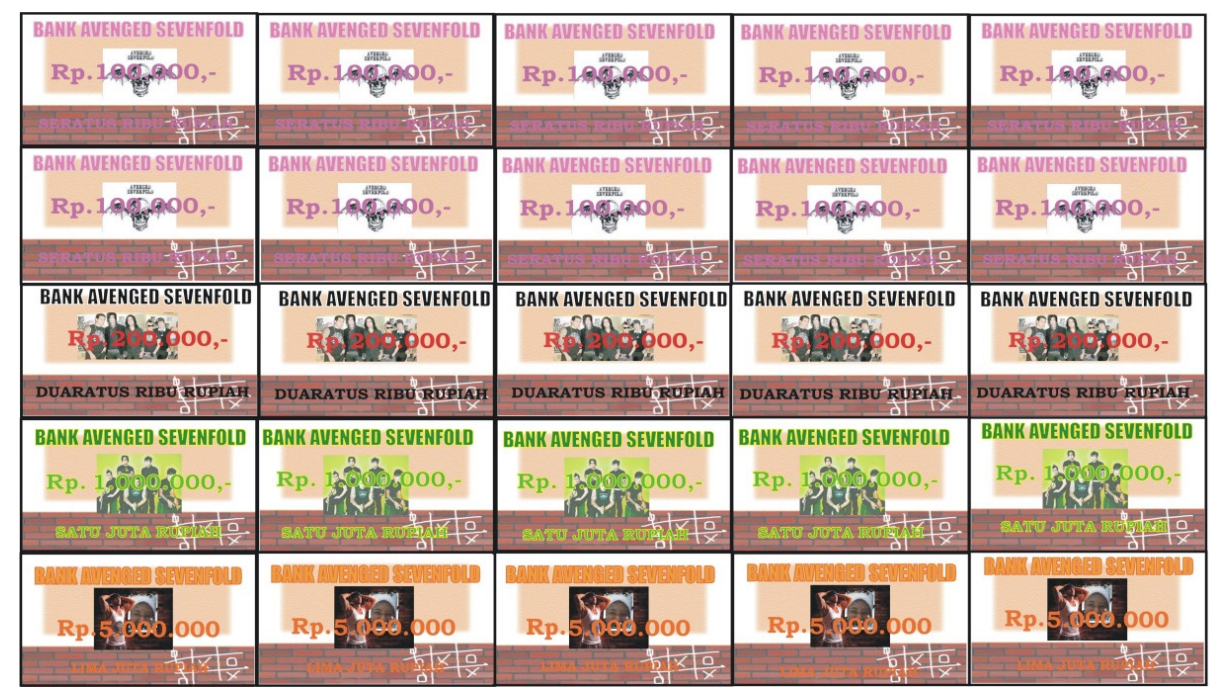

Gambar 3. Sebagian contoh Pecahan Uang dalam Dagang Game

\section{Hasil belajar}

Hasil belajar adalah kemampuankemampuan yang dimiliki siswa setelah ia menerima pengalaman belajarnya. Hasil belajar siswa pada hakikatnya adalah perubahan mencakup bidang kognitif, afektif dan psikomotoris yang berorientasi pada proses belajar mengajar yang dialami siswa (Sudjana, 2005).

Sudjana (2005) menyatakan bahwa hasil belajar itu berhubungan dengan tujuan instruksional dan pengalaman belajar yang dialami siswa Hasil belajar dalam hal ini berhubungan dengan tujuan instruksional dan pengalaman belajar. Adanya tujuan instruksional merupakan panduan tertulis akan perubahan perilaku yang diinginkan pada diri siswa (Sudjana, 2005), sementara pengalaman belajar meliputi apa-apa yang dialami siswa baik itu kegiatan mengobservasi, mengobservasi, membaca, meniru, mencoba sesuatu sendiri, mendengar, mengikuti perintah (Sardiman, 2004).

\section{Jurnal Umum dan Jurnal Khusus Perusahaan Dagang}

Setiap transaksi yang terjadi dalam perusahaan dicatat dalam buku harian atau jurnal. Dalam perusahaan kecil, transaksi yang terjadi, baik jumlah maupun jenisnya relatif sedikit sehingga dalam pencatatannya masih memungkinkan digunakan satu macam buku harian, yaitu jurnal umum. Sebaliknya, untuk perusahaan besar transaksi yang terjadi, baik jumlah maupun jenisnya sangat banyak sehingga jika hanya digunakan satu macam jurnal menjadi tidak praktis atau kurang efisien. Untuk perusahaan yang memiliki transaksi banyak dan beraneka ragam, dalam pencatatannya perlu diadakan pengelompokan atau pemisahan, yaitu untuk transaksi yang sejenis dan sering terjadi, pencatatannya dilakukan dalam satu macam jurnal, yaitu jurnal khusus. Penggunaan jurnal khusus akan lebih menghemat waktu, tenaga, dan biaya. Selain itu, juga memungkinkan adanya pembagian pekerjaan atau pekerjaan pencatatan dapat dilakukan oleh beberapa orang sehingga proses pencatatan akan lebih praktis dan efisien. 
Kerangka Berpikir dan Hipotesis Tindakan Kondisi awal penelitian ini menunjukkan bahwa hasil belajar siswa pada materi konsep akun-akun transaksi usaha dagang rendah. Media Dagang Game memungkinkan siswa dapat lebih mudah memahami transaksi yang terjadi, sehingga akan lebih mudah saat mencatatkannya ke dalam ke jurnal umum dan jurnal khusus. Hipotesis Tindakan dalam penelitian ini adalah Media Dagang Game dapat meningkatkan hasil belajar siswa kelas XII IS 1 MAN Salatiga pada semester 1 tahun ajaran 2016/2017.

\section{Metode Penelitian}

Penelitian dilakukan di kelas XII IS 1 MAN Salatiga, Jl. Wahid Hasyim No, 12 Salatiga, tempat penulis bertugas. Penelitian ini diadakan mulai dari bulan Juli 2016 sampai dengan bulan September 2016. Pengamatan dilakukan untuk mendukung pengumpulan data yang dibutuhkan. Subjek Penelitian, siswa kelas XII IS 1 MAN Salatiga pada semester 1 tahun ajaran 2016/2017 sebanyak 32 siswa. Penelitian ini merupakan pengembangan metode dan strategi pembelajaran. Metode dalam penelitian ini adalah metode penelitian tindakan kelas (Classroom Action Research). Tindakan pada setiap siklus 1 disajikan sebagai berikut; pendahuluan, guru memberikan apersepsi mengenalkan jurnal umum usaha dagang, transaksi yang terjadi dan perbedaannya dengan usaha jasa, siswa mulai melakukan permainan dagang game. Siswa dibagi kelompok masing-masing 4-5 siswa untuk setiap kelompok. Guru menjelaskan aturan main Dagang Game, dan meminta siswa untuk mencatat transaksi yang terjadi, dan menuliskannya ke dalam Jurnal Umum

Tindakan pada siklus 2 adalah guru memperkenalkan jurnal khusus usaha dagang, membagi siswa dalam beberapa kelompok yang beranggotakan 5 siswa. Setiap siswa diberi lembar kerja yang berisi kolom kolom jurnal umum dan jurnal khusus, saat melakukan permainan Dagang Game siswa diminta mencatat semua transaksi yang terjadi dan menginputnya dalam jurnal umum dan jurnal khusus sekaligus. Hal ini diharapkan akan mempermudah siswa memahami hubungan antara jurnal umum dan jurnal khusus, mengapa satu transaksi masuk ke jurnal khusus tertentu.

\section{Hasil Penelitian dan Pembahasannya Deskripsi Kondisi Awal}

Hasil belajar siswa di awal pelajaran pada pra penelitian yang dilakukan menunjukkan bahwa nilai mata pelajaran akuntansi 84,37 $\%$ atau 27 dari 32 siswa kelas XII IS 1 masih berada di bawah Kriteria Ketuntasan Minimal (KKM) 75. Rata-rata nilai siswa adalah 45,63 seperti dalam tabel 1 . Untuk meningkatkan nilai, peneliti melakukan tindakan kelas dengan cara memanfaatkan Media Dagang Game dalam pembelajaran Akuntansi.

Tabel 1. Hasil Belajar Akuntansi siswa XII IS 1 Pra-Penelitian

\begin{tabular}{lc}
\hline \multicolumn{1}{c}{ Keterangan } & $\begin{array}{c}\text { Kondisi Pra } \\
\text { Penelitian }\end{array}$ \\
\hline Rerata & 45,63 \\
\hline Skor Maksimum & 95 \\
\hline Skor Minimal & 20 \\
\hline
\end{tabular}

\section{Deskripsi Hasil Siklus I}

Dalam tindakan siklus I siswa diminta untuk berkelompok bermain permainan Dagang Game, dan mencatat transaksi yang mereka lakukan selama permainan simulasi Dagang Game. Hasilnya pada kompetensi dasar perbedaan akun transaksi usaha dagang dan usaha jasa 
juga pencatatan pada jurnal umum, siswa masih kesulitan menuliskan transaksi yang terjadi ke jurnal umum. Hal ini ditunjukkan dengan skor hasil belajar siswa rata-rata menjadi 71,88 dan siswa belum tuntas di bawah KKM 75 sebanyak 59,75\%.

\section{Deskripsi Hasil Siklus II}

Pada siklus 2 dengan kompetensi dasar menyusun jurnal khusus usaha dagang, siswa diminta berkelompok untuk melakukan permainan simulasi Dagang Game. Selama permainan mereka diminta untuk mencatatnya pada jurnal umum dan sekaligus jurnal khusus. Setiap siswa mencatatnya dalam worksheet yang telah disiapkan. Pada tahap ini siswa melakukan analisis langsung terhadap transaksi yang mereka lakukan. Hasil belajar siswa pada siklus II rata-rata sebesar 81,56 dan siswa belum tuntas sebanyak $21,87 \%$ siswa atau 7 orang siswa dan siswa tuntas $78,12 \%$. Nilai tertinggi 100 dan nilai terendah 55, karena jumlah siswa tuntas sudah lebih dari 75\% maka penelitian tindakan cukup sampai siklus 2 .

\section{Pembahasan}

Dari skor hasil belajar saat kondisi pra penelitian, siklus 1 dan siklus dua dapat terlihat bahwa rerata skor hasil belajar siswa meningkat dari 45,63 di pra penelitian, menjadi 71,88 saat siklus 1 dan rerata siklus 2 sebesar 81,56 dengan 78,12 $\%$ siswa tuntas memiliki skor di atas KKM ditetapkan yaitu 75. Perbandingannya dapat dilihat pada tabel berikut:
Tabel 2. Perbandingan Skor Hasil Belajar Siswa

\begin{tabular}{lrrr}
\hline Keterangan & $\begin{array}{c}\text { Pra } \\
\text { Peneli- } \\
\text { tian }\end{array}$ & $\begin{array}{c}\text { Siklus } \\
\mathbf{1}\end{array}$ & $\begin{array}{c}\text { Siklus } \\
\mathbf{2}\end{array}$ \\
\hline Rerata & 45,63 & 71,88 & 81,56 \\
\hline $\begin{array}{l}\text { Skor } \\
\text { Maksimum }\end{array}$ & 95 & 100 & 100 \\
\hline $\begin{array}{l}\text { Skor } \\
\text { Minimal }\end{array}$ & 20 & 50 & 55 \\
\hline $\begin{array}{l}\text { \% siswa } \\
\text { belum tuntas }\end{array}$ & $84,38 \%$ & $40,63 \%$ & $21,88 \%$ \\
\hline $\begin{array}{l}\text { \% siswa } \\
\text { tuntas }\end{array}$ & $15,63 \%$ & $59,38 \%$ & $78,13 \%$ \\
\hline
\end{tabular}

Peningkatan skor setelah dilakukan tindakan menggunakan media Dagang Game, sejalan dengan penelitian Tanner and Lindquist (1998) dalam Nitkin (2011), setelah menggunakan board monopoli pada kelas junior akuntansi, siswa memiliki persepsi positif pada pembelajaran akuntansi. Gamlath (2007) juga menggunakan board Monopoly untuk mengajar akuntansi, hasilnya siswa meningkat kemampuannya dalam memahami akuntansi, juga keterampilan interpersonalnya, dibandingkan cara tradisional ceramah atau tugas.

Seseorang menyukai permainan dikarenakan beberapa alasan. Para peneliti menemukan dalam sebuah survei terhadap 169 orang dewasa bahwa saat bermain responden menyukai kesempatan untuk "berfantasi dan menghidupkan momenmomen yang tidak biasa" dan menjadi terhibur dengan bermain board game seperti Monopoly dan Scrabble (d'Astous \& Gagnon, 2007). Para peneliti lainnya menemukan bahwa banyak permainan edukatif berguna untuk mempelajari sebuah pengetahuan dan peningkatan keterampilan kerja kelompok (Michaels \& Chen, 2007), meningkatkan kemampuan membuat keputusan (Zapalska, 2006), dan 
menciptakan lingkungan psikologis yang sehat di dalam kelas, selama pelajaran berlangsung (Zapalska, Rudd, \& Flanegin, 2003).

Permainan Dagang Game, dirancang untuk memenuhi kebutuhan gaya belajar siswa visual kinestetis, seperti yang diungkapkan oleh Gregoryk dan Eighmy (2009), Robinson (2006, 2007), Eisner (2004) dalam penelitiannya bahwa cara tradisional belajar ceramah, dengan textbook dan kuis tidak menumbuhkan kemampuan dan minat siswa dalam mempelajari sesuatu, karena siswa cenderung memiliki gaya belajar visual kinestesis. Saat guru mengetahui perubahan ini, mereka mencoba membuat banyak simulasi permainan dan game, pada strategi pembelajaran mereka di kelas (Lippincott and Pergola 2009, Gast and Leathan 2005).

Peningkatan hasil belajar siswa dengan permainan simulasi Dagang Game ini membuktikan hipotesis tindakan yang diajukan dapat diterima. Kemampuan siswa kelas XII IS 1 meningkat dalam memahami pelajaran akuntansi. Permainan simulasi Dagang Game ini membuat siswa mengalami sendiri, apa yang terjadi pada setiap transaksi usaha dagang. Siswa dapat mengatasi kebingungan mereka tentang akun-akun yang timbul saat transaksi, dan siswa dapat memahami pencatatan di Jurnal Umum dan Jurnal Khusus dengan lebih mudah.

\section{Penutup \\ Simpulan}

Media permainan simulasi Dagang Game terbukti dapat meningkatkan hasil belajar siswa. Hal ini ditunjukkan dengan peningkatan rerata skor hasil belajar dari kondisi pra penelitian 45,63 dengan jumlah siswa tuntas 15,63 , kemudian pada siklus 1 skor hasil belajar memiliki rerata 71,88 dengan siswa tuntas 59,38\% dan siklus 2 skor hasil belajar memiliki rerata 81,56 dengan siswa tuntas $78,13 \%$.

\section{Saran}

Saran penelitian bagi guru dan dunia pendidikan yaitu menambah variasi model pembelajaran sebagai alternatif untuk meningkatkan kemampuan siswa memahami pencatatan transaksi dalam jurnal umum dan jurnal khusus usaha dagang, untuk selanjutnya disusun satu siklus akuntansi usaha dagang, meningkatkan keterampilan mengelola kegiatan belajar mengajar.

\section{Daftar Rujukan}

Ashwin, A. (2005). Using games in the classroom. Teaching Business \& Economics, 9 (3), 31.

Aunurrahman, (2009). Belajar dan Pembelajaran. Bandung: Penerbit Alfabeta

D'Astous, A. \& Gagnon, K. (2007). An inquiry into the factors that impact on consumer appreciation of a board game. Journal of Consumer Marketing, 24(2), 80-89.

Chen, S. \& Michaels, D. (2005). Proof of learning: Assessment in serious games. Gamasutra, October 19, 2005, download 29 September 2016, dari (http://www.gamasutra.com/view/ feature/130843/proof_of_learning_ assessment_in_.php)

Eisner, S. (2004). The class talk show: A pedagogical tool. S.A.M. Advanced Management Journal, 69(1), 34-42.

Fowler, L. (2006). Active learning: An empirical study of the use of simulation games in the introductory financial accounting class. Academy of Educational Leadership Journal, 10(3), 93-104. 
Gamlath, S. (2007). Outcomes and Observations of an Extended Accounting Board Game, Development ini Business Simulation and Experiential Learning Journal, Volume 34.

Gast, J. \& Leathan, M. (2005). Jeopardy: A fun interactive approach to teaching theory. American Journal of Health Education, 36(1) 54-57

Gregoryk, K., \& Eighmy, M. (2009). Interaction among undergraduate students: does age matter? College Student Journal, 43(4), 1125-1136.

Hoffjan, A. (2005). Calvados--A business game for your cost accounting course. Issues in Accounting Education, 20(1), 63-80

Homan, S. (2013). Pengaruh Media Monopoli Accounting Game terhadap Tingkat Aktivitas Belajar dan Karakter Jujur. Skripsi. Tidak diterbitkan. Universitas Pendidikan Indonesia.

Lippincott, B., \& Pergola, T. (2009). Use of a job cost simulation to engage gen $\mathrm{Y}$ students. Journal of the International Academy for Case Studies, 15(2), 97113.

Mulyasa, E. (2002). Management berbasis Sekolah. Bandung : Remaja Rosdakarya

Murphy, E. A. (2005). Enhancing student learning with governmental accounting jeopardy! Journal of Public Budgeting, Accounting \& Financial Management, 17(2), 223-248.

Nitkin,(2011). "Game of Business": a Game for Use in Introductory Accounting. The Accounting Educators' Journal. Volume XXI, 2011 pp. 131-152

O'Halloran, R. \& Deale, C. (2009). Designing a Game Based on Monopoly as a Learning Tool for Lodging
Development, Journal of Hospitality \& Tourism Education, Volume 22, Number 3

Robinson, S. (2006). Using games and clickers to encourage students to study and participate. Allied Academies International Conference. Academy of Educational Leadership. Proceedings, 11(2), 25-29.

. (2007). Learning games from the ground up. Allied Academies International Conference. Academy of Educational Leadership. Proceedings, 12(1), 43-46

Sardiman. (2004). Interaksi dan Motivasi Belajar Mengajar. Jakarta: PT Raja Grapindo Persada

Sudjana, N. (2005). Dasar-dasar Proses Belajar Mengajar. Bandung: Balai Pustaka

Tanner, M.M. \& Lindquist, T.M. (1998). Using Monopoly and teams-gamestournaments in accounting education: a cooperative learning teaching resource. Accounting Education, 7(2), 139-162.

Zapalska, A.M., Brozik, D., \& Niewiadomska-Bugaj, M. (2006). Decision-making: Tourism and hospitality game. Journal of Teaching in Travel Tourism, 54(3), 259-270.

Zapalska, A. M., Rudd, D. \& Flanegin, F. (2003). An educational game for hospitality and tourism education. Journal of Teaching in Travel and Tourism, 3(3), 19-36. 